What roles do different forms of RNA play in genome function?

\title{
非编码 RNA 研究概述
}

陈亮，单革*

中国科学技术大学生命科学学院, 中国科学院天然免疫与慢性疾病重点实验室, 合肥 230027

* 联系人, E-mail: shange@ustc.edu.cn

2017-04-05 收稿, 2017-05-27 修回, 2017-05-27 接受, 2017-08-30 网络版发表

国家重点基础研究发展计划(2015CB943000)和国家自然科学基金(31471225, 31600657)资助

摘要 RNA是细胞以DNA为模板产生的转录产物, 根据中心法则, 早期一般将RNA整体地看作从DNA到功 能蛋白质分子的中间信息专递分子。这些分子也是较早为生物学家所认知的 mRNA，rRNA，tRNA等。其中 mRNA直接作为翻译蛋白质的模板，而rRNA及tRNA等的功能则直接保证蛋白质翻译的进行. 20 世纪末及 21 世 纪的研究逐渐让生物学家认识到细胞中还存在多种多样、对于中心法则遗传信息传递并非必需的非编码RNA分 子. 认识RNA分子的种类、功能、机理, 及其与生理、遗传、进化等生命科学重要命题间的相互关系, 是当代 生物学的重要内容. 本文对目前已知的非编码RNA种类、功能及机理, 以及在生理、遗传、进化、生态中的作 用进行概述。同时也简要介绍了非编码RNA相关的生物技术及生物医药应用。非编码RNA研究已经取得了巨大 的进展, 进一步的研究无疑将继续作为当代科学研究的重要领域存在, 从而回答各种各样RNA在基因组功能中 的作用这一问题.

关键词 RNA，非编码 RNA，功能机理，生理，遗传，进化

真核生物基因组具有广泛转录(pervasive transcription)的特性, 产生出大量的、各种各样的转录产 物, 也就是 $\mathrm{RNA}^{[1,2]}$. 例如, 人类基因组至少 $78 \%$ 的序 列会产生相应的转录产物, 而这些转录产物中仅有 不到 $2 \%$ 的序列会作为模版将其序列所含信息 “翻译” 到产生的蛋白质氨基酸序列当中 ${ }^{[3,4]}$.

一定意义上来说，只有 mRNA上的开放阅读框 (open reading frame, ORF)序列才是“编码”序列，而 mRNA上的其他序列及大量的不能够作为翻译模版 的非mRNA转录产物, 称为非编码 RNA序列 ${ }^{\left[{ }^{[}\right.}$-7]. 研 究表明, mRNA上的非编码RNA序列可以调控mRNA 的翻译、定位、稳定性等 ${ }^{[8 \sim 15]}$. 而研究大量的不作为 翻译模版的所谓非编码 RNA (noncoding RNA, ncRNA) 序列的数量、种类、功能及其机理是近十几 年来生物学的重要研究领域.

\section{1 非编码RNA的种类、数量}

在非编码RNA中、被认知和研究得较早的是核糖 体RNA (ribosomal RNA, rRNA), 转运RNA (transfer RNA，tRNA)等所谓行使“管家”(house keeping)功能 的分子. RNA对于几乎每个真核细胞的基本生命活 动都必不可少. 例如, RNA剪切与修饰, mRNA翻译 等。细胞、特别是真核细胞当中，除了多种“管家” (house keeping)非编码RNA以外, 还存在着大量的、 各种各样的其他非编码RNA. 这些非编码RNA往往 并非在各种真核细胞中均具有，而是具有细胞或者 时空特异性的表达. 这些非编码RNA按长度大于或 小于 200 nucleotide (nt) 可以人为分为长链非编码 RNA (long noncoding RNA, lncRNA)和小非编码RNA (有时也简称为小RNA, small noncoding RNA) ${ }^{[16 ~ 18]}$. 进 一步按照其序列特征、生成(biogenesis)、功能、功能

引用格式: 陈亮, 单革. 非编码 RNA 研究概述. 科学通报, 2017, 62: 3236-3244 Chen L, Shan G. A brief introduction of noncoding RNA research (in Chinese). Chin Sci Bull, 2017, 62: 3236-3244, doi: 10.1360/N972017-00384 
机理等特性, 无论是长链非编码 RNA和小非编码 RNA均可以分为多种类型.

最早作为一类小RNA被发现的是microRNA ${ }^{[19-22]}$; 随后是广为人知的piRNA(piwi-interactiing RNA) ${ }^{[23,24]}$. 而最早发现的长链非编码 RNA (long non-coding RNA, IncRNA)为H19和XIST ${ }^{[25 ~ 28]}$. 随着物种进化程 度的递增、小RNA (特别是microRNA)及长链非编码 RNA 的数量也逐步递增. 人类具有数以千计的 microRNA及数以万计的lncRNA.

近年来, 被发现在真核多细胞生物中还存在一 类大量的非编码RNA, 即环形 RNA (circular RNA, circRNA $)^{[29 \sim 31]}$. 目前普遍认为真核细胞中绝大部分 环形RNA是由向后剪切 (back splicing)形成的. 在人 (Homo sapiens)、小鼠(Mus musculus) 几乎各种细胞当 中, 环形RNA的种类可能均达到万种以上.

近 10年来, 随着二代测序 (next generation sequencing, NGS)及生物信息学的发展, 大量多种多样 的非编码RNA被陆续发现. 仅就本研究组而言, 近 几年已发现及命名了外显子-内含子环形RNA (exonintron circular RNA, EIciRNA), 5S-OT (5S overlapped transcript) lncRNA, ASAT siRNA ( $\alpha$-satellite siRNA) 等 ${ }^{[32 ~ 34]}$. 需要特别指出的是, 根据某一大类非编码 RNA中的转录、加工、降解、序列、细胞内定位、功 能及功能机理等特性, 往往又可以分出不同的小类 型(subclass). 例如, piRNA中有一类被称为 pachytene piRNA, 其即具有别于其他piRNA的一些特性. 环形 RNA中也有一类特殊的 subclass, 即EIciRNA.

从种类上, 典型的哺乳动物细胞可能具有分别 以万计的、序列不同的小RNA, 长链非编码RNA以及 环形RNA; 而其中每种序列不同的非编码RNA的分 子数量又可以是从一到数以万计. 完全可以预测未 来还将发现大量的、新的非编码RNA.

\section{2 非编码RNA的功能与功能机理}

非编码RNA以非常多样的分子机制行使着各种 各样的调控功能. 在真核细胞中, 非编码RNA大致 可以分为在细胞核内或在细胞质中行使功能这两种 类型. 在细胞质中, 研究得相对较为系统的是 microRNA对 mRNA的转录后调控. 结构生物学已经 揭示了 microRNA通过结合AGO2对 mRNA转录后调 控的具体反应机理 ${ }^{[35,36]}$. 一些长链非编码RNA也在 细胞质中发挥作用, 其中较多的例子是作为竞争性
内源RNA (competing endogenous RNA, ceRNA)来竞 争性结合 microRNA; ceRNA与microRNA的结合部分 解除了相应 microRNA对其靶 mRNA 的负调控作 用 ${ }^{[37]}$. 近年来, 发现大量存在的环RNA也大量存在 于细胞质中. 其中有个别特例的环RNA以 ceRNA的 方式竞争性结合 microRNA ${ }^{[38,39]}$. 当然, 非编码RNA, 无论小RNA还是长链非编码RNA, 在细胞质中还有 着多种其他调控方式. 例如, 1/2-sbsRNA及BACE1AS调控mRNA的稳定性; lincRNA-p21及AS Uchl1调

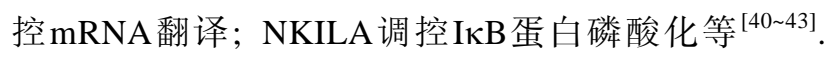
在此不一一详述.

非编码RNA功能机理的特殊之处在于往往不能 简单对某一类非编码RNA一概而论. 仅就microRNA 而言, 已有报道一些microRNA并非通过结合 mRNA 3'UTR 来行使转录后的抑制功能. 例如, 有报道 microRNA可以在线粒体中通过 microRNA/AGO2复 合物的方式起到促进线粒体基因表达的作用，但对 于其详细机理并不非常清楚 ${ }^{[44,45]}$.

还有少数以前认定的所谓长链“非编码RNA”被 发现实际上是编码小肽的“mRNA” ${ }^{[46]}$. 早期往往把 最大可能ORF小于 100 个氨基酸残基、尚未有报道能 编码多肽的RNA被认定为非编码RNA. 目前被认定 编码小肽的几种所谓非编码RNA均为在早期进行大 规模鉴定时被归类为非编码RNA. 目前就转录本已 经可以对小至 10 个氨基酸残基的潜在开放阅读框进 行物种间保守性分析，基本上可以很大程度上消除 将编码小肽的转录本定义为非编码RNA的可能. 目 前看来, 绝大部分在细胞质中现被鉴定为非编码 RNA的转录本应该是起着非编码的功能. 最近有研 究发现, 一些环形RNA在细胞质中也会作为翻译多 肽的模板 ${ }^{[47 ~ 50]}$, 进一步的研究将弄清细胞质中有多 大比例环形RNA可以作为翻译的模板, 以及这些能 作为翻译模板的环形RNA是以其翻译出的多肽还是 依然以其作为RNA分子行使主要生物学功能.

转录、加工生成的RNA如果不被运出细胞核、基 本上是起着非编码的功能. 已知细胞核内非编码 RNA可以通过与DNA、蛋白质以及RNA-RNA之间的 相互作用来行使调控功能. 基本上细胞核内的所有 已知的主要调控均能看到非编码RNA的参与. 例如, enhancer RNA (eRNA) 可能参与了染色质的远程相互 作用; hotair RNA参与了组蛋白修饰调控; Malat1及 人 $5 \mathrm{~S}-\mathrm{OT}$ 参与了 $\mathrm{mRNA}$ 剪切调控; diRNA参与了DNA 
的损伤修复; piRNA参与了异染色质形成及mRNA降 解等 ${ }^{[51 ~ 56]}$. 有趣的是, 对于有些非编码 RNA, 其 RNA分子本身并无调控功能, 而是产生该转录本的 转录过程或转录事件起着调控作用. 无论是在细胞 质, 还是在细胞核内, 很可能还有多种非编码RNA 的调控方式尚待揭示.

\section{3 非编码RNA的生理作用}

大量证据显示, 非编码RNA在动物个体水平上 起着重要的生理调控功能. 其中研究得较早也较多 的是, 雌性哺乳动物(或人类女性)中长链非编码RNA XIST在X染色体随机失活中的关键作用. 表达XIST 的X染色体在以此非编码RNA为主介导的一系列表 观遗传调控事件后被转变为Barr body, 从而完成了 哺乳动物中的 $X$ 染色体剂量补偿 ${ }^{[57,58]}$. 有意思的是, 果蝇(Drosophila melanogaster) 的X染色体剂量补偿 也与长链非编码RNA调控密切相关 ${ }^{[59]}$. 雄性果蝇中 两个长链非编码RNA, rox1和rox2作为形成MSL剂量 补偿复合物(MSL dosage compensation complex)的支 架 (scaffold)来行使功能. NEAT1和MALAT1分别是 哺乳动物细胞中与 paraspeckle和 nuclear speckle形成 及功能相关的长链非编码RNA. 但是令人意外的是, 迄今NEAT1敲除小鼠仅发现具有黄体及乳腺形成缺 陷, 而MALAT1敲除小鼠尚未发现具有任何明显表 型 ${ }^{[60 ~ 62]}$. 一些长链非编码RNA敲除的人或小鼠ES细 胞以及其他细胞系中也显示出一定的表型, 但是对 于绝大部分长链非编码RNA, 目前还缺乏在各种模 式动物、小鼠及人个体水平生理作用的研究.

对于小RNA中piRNA和microRNA的生理功能有 较多的研究. piRNA通路失活在秀丽线虫 (Caenorhabditis elegans)、果蝇、小鼠中均会导致配子发生上 的缺陷 ${ }^{[63,64]}$. 很多microRNA的生理作用已经得到认 识. 在秀丽线虫 (线虫)、果蝇以及小鼠中, 多个 microRNA的突变具有相应表型. 例如, 最先被认识 到的两个microRNA, lin-4及let-7的突变线虫即分别具 有明显发育迟滞和寿命减短 ${ }^{[65 ~ 67]}$. 果蝇的 microRNA bantam突变具有神经发育障碍以及个体偏小等表 型 ${ }^{[68]}$. miR-1突变小鼠存在心律不齐甚至猝死等表 型 ${ }^{[69,70]}$. 也发现很多microRNA突变并无明显表型; 有时需要把一个特定 microRNA簇 (microRNA cluster) 或者microRNA家族(microRNA family)整体敲除才会 表现出明显的表型. 例如, 高除 miR-183/96/182后,
小鼠会出现记忆损伤 ${ }^{[71]}$; 这种结果表明, microRNA 各家族成员具有功能上的圥余(redundancy) ${ }^{[72]}$. 近年 来还发现, 一些非编码RNA (研究得较多的是 microRNA) 存在于外泌体(exosome)中, 可以起到细 胞间调控作用 ${ }^{[73,74]}$. 从这个意义上, 非编码 RNA可 以起到细胞间信号分子样的生理作用. 当然目前对 于大量microRNA以及其他各种非编码RNA的研究也 还停留在细胞水平上, 对于绝大部分非编码的生理 功能还缺乏认知.

\section{4 非编码RNA与生态、获得性遗传、进化}

非编码RNA还参与了物种间以及生物与环境相 互关系. 例如, 人工在大肠杆菌 (Escherichia coli) 中 表达的双链RNA可以进人取食细菌的秀丽线虫细胞 内, 并被加工为 siRNA 而起到 RNA 干扰的作用 (feeding RNAi) ${ }^{[75 \sim 77]}$. 本研究组发现, 大肠杆菌自身 表达的非编码RNA可以进人秀丽线虫细胞内调控基 因表达 ${ }^{[78]}$. 一些植物中的 microRNA, siRNA可以进 人取食这些植物的动物, 如某些昆虫等体内, 并且起 到调控基因表达的作用 ${ }^{[79 ~ 81]}$. 甚至有研究提出, 植 物中的microRNA可以通过消化道吸收进人人和小鼠 等哺乳动物细胞, 并且调控基因表达 ${ }^{[82]}$. 这方面的 研究还有许多问题尚待解答, 甚至还具有争议.

一些遗传现象是以非基因序列依赖的方式进行 的, 这种遗传现象即是所谓非孟德尔遗传, 也可以称 为获得性遗传或者拉马克遗传. 一系列的证据显示, 非编码 RNA参与了特定类型的获得性遗传. 例如, 饥饿处理的秀丽线虫会表现出长寿, 而其十多代内 的后代, 尽管没有经受饥饿, 依然会表现出长寿. 现 有证据表明，小非编码RNA参与了这种跨代遗传 (transgenerational inheritance) ${ }^{[83]}$. 利用feeding RNAi 干扰秀丽线虫特定基因表达也会产生跨代遗传现象. 在亲代进行 feeding RNAi, 而子代不进行 feeding RNAi的情况下, 至少 10 代以内的子代依然表现出特 定基因表达受到干扰. 小非编码 RNA也参与了 feeding RNAi后的跨代遗传现象. 最近的研究表明, 来源于tRNA的片段参与了小鼠中的一种跨代遗传现 象. 高脂饲养的雄性小鼠会具有一系列糖脂代谢异 常, 而其在正常饲料喂养下发育及生长的子代也会 表现出某些糖脂代谢异常. 随后的研究表明, 高脂饲 养的雄性小鼠精子中具有较高水平的tRNA片段, 而 受精卵中注人tRNA片段会导致出生后的小鼠具有糖 
脂代谢异常 ${ }^{[84]}$. 目前, 对于各种拉马克遗传现象的 机理还知之甚少, 而各种非编码RNA也许在其中具 有多种多样的作用.

非编码RNA比蛋白质更具有物种特异性 ${ }^{[85]}$. 极 少数小非编码RNA, 如let-7等数种 microRNA在整个 动物界均保守, 大部分小非编码RNA在序列上并非 保守. 总体而言, 长链非编码RNA序列上的保守性 比小非编码RNA更弱. 本研究组报道了迄今为止唯 一发现的从裂殖酵母 (Saccharomyces) 到人均具有的 长链非编码RNA 5S-OT, 而且发现, 5S-OT在高级灵 长类及人类中进化出了新的序列及功能 ${ }^{[33]}$. 无论是 小非编码RNA还是长链非编码RNA均具有大量某一 类动物甚至某一物种特有的成员. 有科学家认为, 编 码蛋白质的基因可能对于生命活动的重大事件具有 必需的重要性, 所以倾向于非常保守; 而非编码 RNA 主要起到调控作用, 是生命进化以及物种间不 同之处的主要推动因子之一 ${ }^{[86]}$.

\section{5 非编码RNA相关生物技术、生物医学}

非编码RNA已经在生物技术和生物医药领域得 到使用. 早在siRNA作为RNA干扰分子被发现后, 大 量的实验研究即开始使用 $s i R N A$ (或者其他最终能在 细胞内产生 siRNA的方式)进行基因表达敲低实验. 自21世纪初以来, 将siRNA以及 microRNA发展为可 用于治疗人类疾病药物的努力持续不断. 目前研究 发现, 很多非编码RNA在疾病模型中可以作为标记 物, 预示着其可以作为治疗靶点. 例如, mir-21被发 现在近乎所有的肿瘤中都高表达 ${ }^{[87]}$; 小 RNA簇 (microRNA cluster) miR-182-96-183也被证实参与到 多个肿瘤发生进程 ${ }^{[88]}$. 长非编码RNA PCA3 在前列 腺癌中高表达, 检测PCA3的PROGENSA PCA3分子 检测试剂已被美国食品药品监督管理局(Food and Drug Administration, FDA)批准 ${ }^{[89,90]}$.

早在 20 世纪90年代初, RNA适配体 (RNA aptamer) 作为可以结合特定配体 (一般为蛋白质、小分子 甚至细胞)的人工小非编码RNA概念被提出并被笁选 出来 ${ }^{[91 ~ 93]}$. 在实验研究中, RNA适配体经常被用于结 合特异蛋白质. 本研究组即利用一种我们改进的篎 选方法, 得到了能特异识别p53点突变蛋白的RNA适 配体, 而且此适配体在人肿瘤细胞中能部分回复p53 点突变蛋白的功能 ${ }^{[94]}$. RNA适配体也可发展为用于 治疗人类疾病的药物. 目前已经有一种FDA批准的
RNA适配体药物用于临床, 并有多种RNA适配体药 物已经进入临床实验 ${ }^{[05,96]}$.

最近数年来取得实质性进展的、以非编码RNA 为基础的生物技术是CRISPR(Clustered regularly interspaced short palindromic repeats ${ }^{[97 \sim 100]}$. CRISPR 是 很多细菌具有的、将外源DNA以重复序列方式整合 人自身基因组特定位点, 并在随后可以外源DNA重 复序列为模板转录出非编码RNA (sgRNA); 进而细 菌利用 $\operatorname{sgRNA}$ 可以指导切割, 随后再侵人具有相同 序列的外源 DNA. CRISPR 实际上是细菌对抗外源 DNA的一种天然免疫方式. 目前CRISPR已大量应用 于实验研究当中, 其各种衍生方法被用来敲除基因、 敲人基因或DNA片段、上调或下调基因表达. 利用 CRISPR 治疗人类遗传性疾病的尝试也正在开 展 ${ }^{[101 ~ 103]}$.

除以上较为广泛及大量被应用的非编码RNA相 关技术, 很多其他非编码RNA也正在被研发或者已

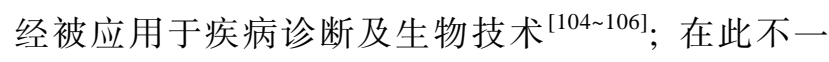
一赘述.

\section{6 研究展望}

目前生物学界基本上认同各种各样的非编码 RNA存在于生命之中, 其中很多(如果不是全部的话) 起着重要功能. 例如, 16S核糖体RNA, RNase P RNA 等起着 RNA酶作用的 RNA, 是地球生命开始之初的 RNA世界(RNA world)即具有的非编码 $R_{N A}{ }^{[107]}$. 随着 生命的进化, 各种各样的非编码RNA作为重要的精细 调控物种特异性调控分子出现. 非编码RNA甚至可能 作为“中性”(中性漂变学说(neutral theory of molecular evolution)) 分子, 为进化提供可能, 为重要非编码 RNA功能分子及新编码基因起源提供材料 ${ }^{[108]}$.

已被发现的非编码RNA种类繁多, 功能及机理 呈多样性. 毫无疑问, 将来还会发现更多类型的非编 码RNA及更广泛多样的非编码RNA的功能和作用机 理. 而对于非编码RNA在遗传、进化、生态中的作用 的认识也将逐渐深人. 随着基础研究的进行, 非编码 RNA相关的生物技术及生物医学应用也必将得到进 一步发展. Science于 2005 年提出 125 个科学前沿问题 时, 认为是未来四分之一世纪需要重点研究的. 完全 有理由相信, 到 2030 年时, 人类对各种RNA分子的 多样的功能会有更加深人的认知, 并且已经可以较 为广泛地利用RNA作为生物医学和生物技术手段. 


\section{参考文献}

1 Crick F H. On protein synthesis. Symp Soc Exp Biol, 1958, 12: 138-163

2 Geiduschek E P, Haselkorn R. Messenger RNA. Annu Rev Biochem, 1969, 38: 647-676

3 International Human Genome Sequencing Consortium. Finishing the euchromatic sequence of the human genome. Nature, 2004, 431: 931-945

4 Ponting C P, Oliver P L, Reik W. Evolution and functions of long noncoding RNAs. Cell, 2009, 136: 629-641

5 Quinn J J, Chang H Y. Unique features of long non-coding RNA biogenesis and function. Nat Rev Genet, 2016, 17: 47-62

6 Cech T R, Steitz J A. The noncoding RNA revolution-trashing old rules to forge new ones. Cell, 2014, 157: 77-94

7 Guttman M, Rinn J L. Modular regulatory principles of large non-coding RNAs. Nature, 2012, 482: 339-346

8 Lee J T. Epigenetic regulation by long noncoding RNAs. Science, 2012, 338: 1435-1439

9 Castel S E, Martienssen R A. RNA interference in the nucleus: Roles for small RNAs in transcription, epigenetics and beyond. Nat Rev Genet, 2013, 14: 100-112

10 Ulitsky I, Bartel D P. lincRNAs: Genomics, evolution, and mechanisms. Cell, 2013, 154: 26-46

$11 \mathrm{Hu} \mathrm{S}$, Wu J, Chen L, et al. Signals from noncoding RNAs: Unconventional roles for conventional pol III transcripts. Int J Biochem Cell Biol, 2012, 44: 1847-1851

12 Liu J, Valencia-Sanchez M A, Hannon G J, et al. MicroRNA-dependent localization of targeted mRNAs to mammalian P-bodies. Nat Cell Biol, 2005, 7: 719-723

13 Meng L F, Chen L, Li Z Y, et al. Environmental RNA interference in animals. Chin Sci Bull, 2013, 58: 4418-4425

14 Fu X. Non-coding RNA: A new frontier in regulatory biology. Natl Sci Rev, 2014, 1: 190-204

15 Belew A T, MeskauskasA, Musalgaonkar S, et al. Ribosomal frameshifting in the CCR5 mRNA is regulated by miRNAs and the NMD pathway. Nature, 2014, 512: 265-269

16 Ravasi T, Suzuki H, Pangetal K C. Experimental validation of the regulated expression of large numbers of non-coding RNAs from the mouse genome. Genome Res, 2006, 16: 11-19

17 Batistaand P J, Chang H Y. Longnoncoding RNAs: Cellular address codes in development and disease. Cell, 2013, 152: 1298-1307

18 Lee J T, Bartolomei M S. X-inactivation, imprinting, and long noncoding RNAs in health and disease. Cell, 2013, 152: 1308-1323

19 Lee R C, Feinbaum R L, Ambros V, et al. The C. elegans heterochronic gene lin-4 encodes small RNAs with antisense complementarity to lin-14. Cell, 1993, 75: 843-854

20 Wightman B, Ha I, Ruvkun G. Posttranscriptional regulation of the heterochronic gene lin-14 by lin-4 mediates temporal pattern formation in C. elegans. Cell, 1993, 75: 855-862

21 Ambros V. The functions of animal microRNAs. Nature, 2004, 431: 350-355

22 Bartel D P. MicroRNAs: Genomics, biogenesis, mechanism, and function. Cell, 2004, 116: 281-297

23 Seto A G, Kingston R E, Lau N C. The coming of age for PIWI proteins. Mol Cell, 2007, 26: 603-609

24 Siomi M C, Sato K, Pezic D, et al. PIWI-interacting small RNAs: The vanguard of genome defence. Nat Rev Mol Cell Biol, 2011, 12: $246-258$

25 Pachnis V, Belayew A, Tilghman S M. Locus unlinked to a fetoprotein under the control of the murine raf and Rif genes. Proc Natl Acad Sci USA, 1984, 81: 5523-5527

26 Poirier F, Chan C T, Timmons P M, et al. The murine H19 gene is activated during embryonic stem cell differentiation in vitro and at the time of implantation in the developing embryo. Development, 1991, 113: 1105-1114

27 Davis R L, Weintraub H, Lassar A B. Expression of a single transfected cDNA converts fibroblasts to myoblasts. Cell, 1987, 51: 987-1000

28 Wutz A. Gene silencing in X-chromosome inactivation: Advances in understanding facultative heterochromatin formation. Nat Rev Genet, 2011, 12: 542-553

29 Sanger H L, Klotz G, Riesner D, et al. Viroids are single-stranded covalently closed circular RNA molecules existing as highly base-paired rod-like structures. Proc Natl Acad Sci USA, 1976, 73: 3852-3856

30 Gould A R. Studies on encapsidated viroid-like RNA. II. Purification and characterization of a viroid-like RNA associated with velvet tobacco mottle virus (VTMoV). Virology, 1981, 108: 123-133

31 Kos A, Dijkema R, Arnberg A C, et al. The hepatitis delta (delta) virus possesses a circular RNA. Nature, 1986, 323: 558-560

$32 \mathrm{Li} \mathrm{Z}$, Huang C, Bao C, et al. Exon-Intron circular RNAs regulate transcription in the nucleus. Nat Struct Mol Biol, 2015, 22: 256-264 
33 Hu S, Wang X, Shan G. Insertion of an Alu element in an lncRNA leads to primate specific modulation of alternative splicing. Nat Struct Mol Biol, 2016, 23: 1011-1019

34 Huang C, Wang X, Liu X, et al. RNAi pathway participates in chromosome segregation in mammalian cells. Cell Discov, 2015, 1: 15029

35 Chendrimada T P, Gregory R I, Kumaraswamy E, et al. TRBP recruits the Dicer complex to Ago 2 for microRNA processing and gene silencing. Nature, 2005, 436: 740-744

36 Birchler J A, Kavi H H. Molecular biology. Slicing and dicing for small RNAs. Science, 2008, 320: 1023-1024

37 Kumar M S, Armenteros-Monterroso E, East P, et al. HMGA2 functions as a competing endogenous RNA to promote lung cancer progression. Nature, 2014, 505: 212-217

38 Memczak S, Jens M, Elefsinioti A, et al. Circular RNAs are a large class of animal RNAs with regulatory potency. Nature, 2013, 495: $333-338$

39 Hansen T B, Jensen T I, Clausen B H, et al. Natural RNA circles function as efficient microRNA sponges. Nature, 2013, 495: 384-388

40 Kim Y K, Furic L, Parisien M, et al. Staufen1 regulates diverse classes of mammalian transcripts. EMBO J, 2007, 26: 2670-2681

41 Faghihi M A, Modarresi F, Khalil A M, et al. Expression of a noncoding RNA is elevated in Alzheimer's disease and drives rapid feed-forward regulation of beta-secretase. Nat Med, 2008, 14: 723-730

42 Huarte M, Guttman M, Feldser D, et al. A large intergenic noncoding RNA induced by p53 mediates global gene repression in the p53 response. Cell, 2010, 142: 409-419

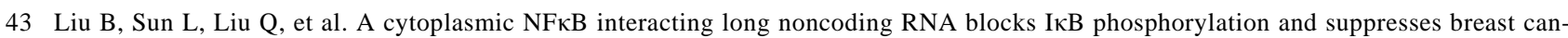
cer metastasis. Cancer Cell, 2015, 27: 370-381

44 Kren B T, Wong P Y, Sarver A, et al. MicroRNAs identified in highly purified liver-derived mitochondria may play a role in apoptosis. RNA Biol, 2009, 6: 65-72

45 Zhang X, Zuo X, Yang B, et al. MicroRNA directly enhances mitochondrial translation during muscle differentiation. Cell, 2014, 158: $607-619$

46 Anderson D M, Anderson K M, Chang C L, et al. A micropeptide encoded by a putative long noncoding RNA regulates muscle performance. Cell, 2015, 160: 595-606

47 Yang Y, Fan X, Mao M, et al. Extensive translation of circular RNAs driven by $N^{6}$-methyladenosine. Cell Res, 2017, 27: 626-641

48 Pamudurti N R, Bartok O, Jens M, et al. Translation of circRNAs. Mol Cell, 2017, 66: 9-21

49 Legnini I, Di Timoteo G, Rossi F, et al. Circ-ZNF609 is a circular RNA that can be translated and functions in myogenesis. Mol Cell, 2017

50 Abe N, Matsumoto K, Nishihara M, et al. Rolling circle translation of circular RNA in living human cells. Sci Rep, 2015, 5: 16435

51 Kim T K, Hemberg M, Gray J M, et al. Widespread transcription at neuronal activity-regulated enhancers. Nature, 2010, 465: 182-187

52 Li W, Notani D, Ma Q, et al. Functional roles of enhancer RNAs for oestrogen-dependent transcriptional activation. Nature, 2013, 498: $516-520$

53 Rinn J L, Kertesz M, Wang J K, et al. Functional demarcation of active and silent chromatin domains in human $H O X$ loci by noncoding RNAs. Cell, 2007, 129: 1311-1323

54 Tsai M C, Manor O, Wan Y, et al. Long noncoding RNA as modular scaffold of histone modification complexes. Science, 2010, 329: 689-693

55 Brown J A, Valenstein M L, Yario T A, et al. Formation of triple-helicalstructures by the 3'-end sequences of MALAT1 and MENbeta noncoding RNAs. Proc Natl Acad Sci USA, 2012, 109: 19202-19207

56 Doksani Y, de Lange T. The role of double-strand break repair pathways at functional and dysfunctional telomeres. Cold Spring Harb Perspect Biol, 2014, 6: 345-356

57 Brockdorff N, Turner B M. Dosage compensation in mammals. Cold Spring Harb Perspect Biol, 2015, 7: a019406

58 Barr M L, Bertram E G. A morphological distinction between neurones of the male and female, and the behaviour of the nucleolar satellite during accelerated nucleoprotein synthesis. Nature, 1949, 163: 676-677

59 Borsani G, Tonlorenzi R, Simmler M C, et al. Characterization of a murine gene expressed from the inactive X chromosome. Nature, 1991, 351: 325-329

60 Nakagawa S, Ip J Y, Shioi G, et al. Malat1 is not an essential component of nuclear speckles in mice. RNA, 2012, 18: 1487-1499

61 Zhang B, Arun G, Mao Y S, et al. The lncRNA Malat1 is dispensable for mouse development but its transcription plays a cis-regulatory role in the adult. Cell Rep, 2012, 2: 111-123

62 Clemson C M, Hutchinson J N, Sara S A, et al. An architectural role for a nuclear noncoding RNA: NEAT1 RNA is essential for the structure of paraspeckles. Mol Cell, 2009, 33: 717-726

63 Muller F L, Colla S, Aquilanti E, et al. Passenger deletions generate therapeutic vulnerabilities in cancer. Nature, 2012, 488: 337-342 
64 Casey S C, Tong L, Li Y, et al. MYC regulates the antitumor immune response through CD47 and PD-L1. Science, 2016, 352: 227-231

65 Chalfie M, Horvitz H R, Sulston J E. Mutations that lead to reiterations in the cell lineages of C. elegans. Cell, 1981, 24: 59-69

66 Ambros V. A hierarchy of regulatory genes controls a larva-to-adult developmental switch in C. elegans. Cell, 1989, 57: 49-57

67 Meng L, Chen L, Li Z, et al. Roles of microRNAs in the Caenorhabditis elegans nervous system. J Genet Genom, 2013, 40: 445-452

68 Hipfner D R, Weigmann K, Cohen S M. The bantam gene regulates Drosophila growth. Genetics, 2002, 161: 1527-1537

69 Yang B, Lin H, Xiao J, et al. The muscle-specific microRNA miR-1 regulates cardiac arrhythmogenic potential by targeting GJA1 and KCNJ2. Nat Med, 2007, 13: 486-491

70 Zhao Y, Ransom J F, Li A, et al. Dysregulation of cardiogenesis, cardiac conduction, and cell cycle in mice lacking miRNA-1-2. Cell, 2007, 129: 303-317

71 Woldemichael B T, Jawaid A, Kremer E A, et al. The microRNA cluster miR-183/96/182 contributes to long-term memory in a protein phosphatase 1-dependent manner. Nat Common, 2016, 7: 12594

72 Song R, Walentek P, Sponer N, et al. miR-34/449 miRNAs are required for motile ciliogenesis by repressing cp110. Nature, 2014, 510: 115-120

73 Zhang L, Zhang S, Yao J, et al. Microenvironment-induced PTEN loss by exosomal microRNA primes brain metastasis outgrowth. Nature, 2015, 527: 100-104

74 Thomou T, Mori M A, Dreyfuss J M, et al. A dipose-derived circulating miRNAs regulate gene expression in other tissues. Nature, 2017, 542: 450-455

75 Fire A, Xu S, Montgomery M K, et al. Potent and specific genetic interference by double-stranded RNA in Caenorhabditis elegans. Nature, 1998, 391: 806-811

76 Tabara H, Grishok A, Mello C C. RNAi in C. elegans: Soaking in the genome sequence. Science, 1998, 282: 430-431

77 Timmons L, Fire A. Specific interference by ingested dsRNA. Nature, 1998, 395: 854

78 Liu H, Wang X, Wang H D, et al. Escherichia coli noncoding RNAs can affect gene expression and physiology of Caenorhabditis elegans. Nat Common, 2012, 25: 1073

79 Bellafiore S, Briggs S P. Nematode effectors and plant responses to infection. Curr Opin Plant Biol, 2010, 13: 442-448

80 Maule A G, McVeigh P, Dalzell J J, et al. An eye on RNAi in nematode parasites. Trends Parasitol, 2011, 27: 505-513

81 Lilley C J, Davies L J, Urwin P E. RNA interference in plant parasitic nematodes: A summary of the current status. Parasitology, 2012, 139: 630-640

82 Zhang L, Hou D, Chen X, et al. Exogenous plant mir168a specifically targets mammalian LDLRAP1: Evidence of cross-kingdom regulation by microRNA. Cell Res, 2012, 22: 107-126

83 Houri-Ze'evi L, Korem Y, Sheftel H, et al. A Tunable mechanism determines the duration of the transgenerational small RNA inheritance in C. elegans. Cell, 2016, 165: 88-99

84 Chen Q, Yan M, Cao Z, et al. Sperm tsRNAs contribute to intergenerational inheritance of an acquired metabolic disorder. Science, 2016, 351: 397-400

85 Pasquinelli A E, Reinhart B J, Slack F, et al. Conservation of the sequence and temporal expression of let-7 heterochronic regulatory RNA. Nature, 2000, 408: 86-89

86 Haudry A, Platts A E, Vello E, et al. An atlas of over 90000 conserved noncoding sequences provides insight into crucifer regulatory regions. Nat Genet, 2013, 45: 891-898

87 Kumarswamy R, Volkmann I, Thum T. Regulation and function of miRNA-21 in health and disease. RNA Biol, 2011, 8: 706-713

88 Mihelich B L, Khramtsova E A, Arva N, et al. MiR-183-96-182 cluster is overexpressed in prostate tissue and regulates zinc homeostasis in prostate cells. J Biol Chem, 2011, 286: 44503-44511

89 Tinzl M, Marberger M, Horvath S, et al. DD3PCA3 RNA analysis in urine-A new perspective for detecting prostate cancer. Eur Urol, 2004, 46: 182-187

90 De Kok J B, Verhaegh G W, Roelofs R W, et al. DD3PCA3, a very sensitive and specific marker to detect prostate tumors. Cancer Research, 2002, 62: 2695-2698

91 Tuerk C, Gold L. Systematic evolution of ligands by exponential enrichment: RNA ligands to bacteriophage T4 DNA polymerase. Science, 1990, 249: 505-510

92 Ellington A D, Szostak J W. In vitro selection of RNA molecules that bind specific ligands. Nature, 1990, 346: 818-822

93 Bock L C, Griffin L C, Latham J A, et al. Selection of single-stranded DNA molecules that bind and inhibit human thrombin. Nature, 1992, 355: 564-566

94 Chen L, Rashid F, Shah A, et al. The isolation of an RNA aptamer targeting to p53 protein with single amino acid mutation. Proc Natl Acad Sci USA, 2015, 112: 10002-10007 
Gragoudas E S, Adamis A P, Cunningham E T, et al. Pegaptanib for neovascular age-related macular degeneration. N Engl J Med, 2004, 351: 2805-2816

96 Ng E W, Shima D T, Calias P, et al. Pegaptanib, a targeted anti-VEGF aptamer for ocular vascular disease. Nat Rev Drug Discov, 2006, 5: $123-132$

97 Horvath P, Barrangou R. CRISPR/Cas, the immune system of bacteria and archaea. Science, 2010, 327: 167-170

Marraffini L A, Sontheimer E J. CRISPR interference: RNA-directed adaptive immunity in bacteria and archaea. Nat Rev Genet, 2010, 11: $181-190$

99 Redman M, King A, Watson C, et al. What is CRISPR/Cas9? Archives of disease in childhood. Educ Prac Ed, 2016, 101: 213-215

100 Barrangou R, Fremaux C, Deveau H, et al. CRISPR provides acquired resistance against viruses in prokaryotes. Science, 2007, 315: 1709-1712

101 Modell J W, Jiang W, Marraffini L A. CRISPR-Cas systems exploit viral DNA injection to establish and maintain adaptive immunity. Nature, 2017, 544: 101-104

102 Shimokawa M, Ohta Y, Nishikori S, et al. Visualization and targeting of LGR5 ${ }^{+}$human colon cancer stem cells. Nature, 2017, 545: $187-192$

103 Cloney R. Genetic screens: CRISPR-based mapping of genetic interactions. Nat Rev Genet, 2017, 18: 272-273

104 Shalem O, Sanjana N E, Hartenian E, et al. Genome-scale CRISPR-Cas9 knockout screening in human cells. Science, 2014, 343: 84-87

105 van Diemen F R, Kruse E M, Hooykaas M J, et al. CRISPR/Cas9-mediated genome editing of herpesviruses limits productive and latent infections. PLoS Pathog, 2016, 12: e1005701

106 Liu Y, Zhan Y, Chen Z, et al. Directing cellular information flow via CRISPR signal conductors. Nat Methods, 2016, 13: 938-944

107 Gilbert W. The RNA world. Nature, 1986, 319: 618

108 Kimura M. Rare variant alleles in the light of the neutral theory. Mol Biol and Evolution, 1983, 1: 84-93

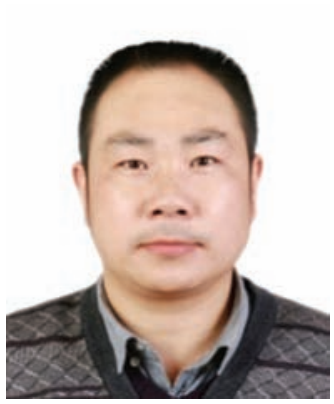

\section{单革}

博士, 中国科学技术大学生命科学学院教授. 1995 年于兰州大学获得细胞生 物学学士学位, 1998 年于中国科学院上海细胞生物学研究所获得硕士学位, 2005 年于美国佐治亚州立大学获得博士学位. 先后在美国爱默蕾(Emory)大 学和耶鲁大学进行博士后研究 (师从 RNA 酶共同发现人 Sidney Altman 教授). 2010 年进入中国科学技术大学工作. 长期从事基因表达调控和非编码 RNA 功能及功能机理方面的研究. 发现了新的非编码 RNA 类型(如 EIciRNA, 5S-OT, ASAT siRNA 等), 研究了新的非编码 RNA 功能, 揭示了新的非编码 RNA 作用机理, 探索了新的非编码 RNA 研究方法. 实验室成立以来在 Nat Struct Mol Biol (2015; 2016), Nat Commun (2012)和Proc Natl Acad Sci USA (2015)发表多篇非编码 RNA 领域的研究论文. 
Summary for “非编码 RNA 研究概述”

\title{
A brief introduction of noncoding RNA research
}

\author{
CHEN Liang \& SHAN Ge* \\ CAS Key Laboratory of Innate Immunity and Chronic Disease, School of Life Sciences, University of Science and Technology of China, Hefei \\ 230027, China \\ * Corresponding author, E-mail: shange@ustc.edu.cn
}

RNAs are products of transcription with DNA as their template. In early days of molecular biology and as suggested in the central dogma, RNAs had been viewed as information carrier to transfer genetic information from DNA to functional proteins. This is true for those RNAs discovered earlier by biologists such as mRNAs, rRNAs, tRNAs, snRNAs, and etc. mRNAs are template of translation to give rise to proteins, whereas snRNAs, rRNAs, tRNAs, and some other noncoding RNAs (ncRNAs) are either directly responsible for the correct produce of mRNAs or essential molecules in the process of protein translation. Starting around the last decade of the 21st century and continuing in this century, biologists have increasingly realized that a great number of diverse ncRNAs are present in cells, and they are versatile molecules but not essential for the information flow suggested by the central dogma. RNAs were presumbly precursor molecules in first life forms on earth, as proposed in the RNA world hypothesis. Over the period of evolutionary time, the genetic information was stored in more stable DNA, while most catalytic and structural functions were handed over to more versatile proteins. Some RNAs still function as essential enzymes in current life forms, and a lot RNAs function as intermediates between genes and proteins. On the other hand, pervasive transcription of eukaryotic genome generates abundant ncRNAs. Accuminating findings demonstrate that a lot of ncRNAs are critical regulators in a plethora of life events, which also suggests that ncRNAs may be one of major driving forces in the evolution of life. The first wave in ncRNA studies is on small noncoding RNAs, e.g. microRNAs and piRNAs; then the field of long noncoding RNAs emerges. It has become one of the focuses of modern biology to know the inventroy, functions, functional mechanisms, physiological significances, ecological roles, relevance to inheritance, and involvement in evolution of ncRNAs. Here we briefly introduce our current understandings about categories of ncRNAs. An enormous number of small, long, and more recently circular, ncRNAs are identified in eukaryotic cells. They function in the cytoplasm, in the nucleus, intercellularly, or even interspecies, with a great variety of mechanisms. We have a concise summary about their roles in physiology, inheritance, evolution, and ecology. NcRNAs generally function through interacting with proteins, DNA, or other RNAs (coding or noncoding). We also have a short disscussion about biotechnologies and biomedical applications derived from ncRNAs. It is speculated that more ncRNA catagories (or subtypes, or novel members of known catagory) will be identified in the future. New roles and functional mechanisms will also be uncovered. Great progresses have been made in the field of ncRNAs, and to decipher ncRNAs will undoubtedly remain to be a significant area of research for the coming decades, which would eventually answer the question of "what roles do different forms of RNA play in genome function".

\section{RNA, noncoding RNA, functional mechanism, physiology, inheritance, evolution}

doi: 10.1360/N972017-00384 